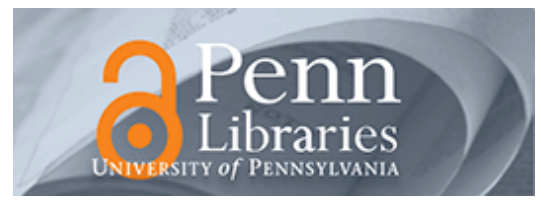

University of Pennsylvania

ScholarlyCommons

Marketing Papers

Wharton Faculty Research

$12-1984$

\title{
Commentary on "Publishing Opinions: A Note on the Usefulness of Commentaries"
}

J. Scott Armstrong

University of Pennsylvania, armstrong@wharton.upenn.edu

Follow this and additional works at: https://repository.upenn.edu/marketing_papers

Part of the Marketing Commons

\section{Recommended Citation}

Armstrong, J. S. (1984). Commentary on "Publishing Opinions: A Note on the Usefulness of

Commentaries". American Psychologist, 39 (12), 1496-. http://dx.doi.org/10.1037/0003-066X.39.12.1496

This paper is posted at ScholarlyCommons. https://repository.upenn.edu/marketing_papers/204

For more information, please contact repository@pobox.upenn.edu. 


\title{
Commentary on "Publishing Opinions: A Note on the Usefulness of Commentaries"
}

\author{
Abstract \\ Comments on J. J. Christensen-Szalanski and L. R. Beach's (see record 1984-21471-001) conclusion that \\ the attention given to commentaries and replies to articles did not justify the extra space. The author \\ indicates that a $40 \%$ increase in space was associated with a $91 \%$ increase in citations; data do not argue \\ against the use of commentaries. \\ Disciplines \\ Business | Marketing
}




\section{Commentary on "Publishing Opinions: A Note on the Usefulness of Commentaries"}

J. Scott Armstrong

University of Pennsylvania

Christensen-Szalanski and Beach (December

1983) concluded that the attention

given to commentaries and

replies to articles did not justify the

extra space. Here is another way to

look at their data. The increase in

journal space due to commentaries and replies was $40 \%$ in their sample.

The "attention" given to the original article plus commentaries plus replies, was, they said, assessed by the number of citations (not counting cross-citations among the commentary and replies).

The median of 21 citations for the articles plus commentaries was $91 \%$ larger than the median of 11 citations for the articles in the control group. In other words, a $40 \%$ increase in space was associated with a $91 \%$ increase in citations. Looking at it this way, these data do not argue against the use of commentaries. In the interest of fairness, I must admit to being an editor, a commentator, and the target of commentators on numerous occasions. Although some commentators did not seem to invest much energy, many did. My impression is that the efforts were useful overall. But I am biased. Commentaries may serve the useful function of pointing out errors in a paper-thus leading to fewer citations. From my experience, the commentaries added emphasis and helped in the understanding of important contributions-thus leading to more citations and to classroom use.

I agree with Christensen-Szalanski and Beach on the need for guidelines that call for short commentaries.

The editor can then relax the requirement for commentators who add data.

\section{REFERENCE}

Christensen-Szalanski, J. J. J., \& Beach, L. R. (1983). Publishing opinions: A note on the usefulness of commentaries. American Psychologist, -38, 1400-1401.

December 1984 • American Psychologist 